\title{
Improve Introducing the Concept of Space through Fantasy Gymnastics for Mentally Handicapped Children
}

\author{
Ardisal \\ Special Education Departement \\ Universitas Negeri Padang \\ ardisalarnev@gmail.com
}

\author{
Pinna Patika Sari Almar \\ Special Education Departement \\ Universitas Negeri Padang \\ ardisalarnev@gmail.com
}

\begin{abstract}
This research is inspired by the problem which found in SLB Muhammadiyah Pauh IX Padang, a child suffered mental retardation has problem on identifying the concept of space. It is seen during the research toward a child and the result showed that there is low ability on identifying the concept of space. This research is aimed to improve children ability on identifying the concept of space through gymnastic fantasy based on stories for early-suffered mental retardation X III class in SLB Muhammadiyah Pauh IX Padang.The method has been used in this research is Single Subject Research (SSR). It used design A1-B-A2 base line was the first condition of mental retardation before treatment and action was given. Condition $B$ (intervention), The child was given action through Gymnastic Fantasy based on stories. In the other hand, condition A2 was the first condition after the intervention did not conducted no more. Mean level condition based line A1 is 5,8 mean level condition of intervention. $B$ is 15,33 and mean level condition of baseline (A2) is 17,6 . The result of the data analysis in conditions and among conditions have an approximate estimation of purpose preference, stability, data history, and change of level showed ability improvement on identifying space concept positifly. Overlap data in the analysis among conditions. Baseline (A1) and intervention condition (B) is $0 \%$ and overlap data in baseline (A2) dan intervention(B) is $\mathbf{2 0 \%}$. Based on the analysis above, it shows that the hipotesys is acceptable. This case is also showed that Gymnastic Fantacy based on stories can improve the ability of indentifying the concept of space for early-suffered mental retardation.
\end{abstract}

Keyword--fantasy gymnastics accordin; the story; children with low mentally disabled.

\section{INTRODUCTION}

Based on the introduction study through observation and interviews that the author did in SLB Muhammadiyah Pauh IX Padang in October to November 2016, the author observed a 3rd grade C1 SDLB, at the time of social science subjectslearning. When the learning process went on, the teacher gave a child a question such as: "Where is the position of the board? " The child appeared to be silent and pointed to the blackboard in front of him without mentioning the direction of the blackboard. The teacher asked the child again, " Who can answer raise your right hand? 'Children held up his right hand and left hand alternately with unhappy face and hesitant because the right hand which was meant by teachers was not known by the child.

Seeing this condition the teacher explains to the child that the blackboard is located in front of the class and while holding up our hands used the right hand that we used to eat. Furthermore, the teacher asked the child to show the right eye and left eye, the child was still hesitant in showing the right eye and left eye by closing both eyes with his hand. Then the teacher corrected the child's movement. At the time of learning the child took off his shoes and the teacher told the child to wear her shoes back, it appeared the child instantly wore shoes in reverse way. Then the teacher explained to the child how to wear the right shoes. Teacher also explained to the children that the concept of space is very important in everyday life such as wearing shoes, wearing pants, wearing clothes, and wearing skirts for women.

The child that the writer observes is an eleven-yearold female currently sitting in grade 3 C1 SDLB. Furthermore, the authors observed the abusive motor skills of children is good as walking, running, and jumping. Similarly, the fine motor is also good as a child is able to hold a pencil well, thickening the point, and connect the two points into lines. But unlike the concept of the space the child was experiencing barrier, the child was unable to distinguish right-left, topdown, and front-back.

The effort that teachers have done during learning to recognize the concept of space in children with mild mental retardation is by using lecture and demonstration methods. In the lecture method the teacher explains about the kind of concepts of space such as right-left, front-back, up and down. Through the demonstration method the teacher demonstrated according to the types of space concepts such as the left hand, the teacher demonstrated by raising the left hand, right hand, the teacher demonstrated by raising the right hand. Teachers also use media that were around (myself, study areas) that made young people motivated to follow the example lesson, the teacher asked the child to name of any object that was in front of the class. Based on the learning process that is done by the teacher, the child still did not understand the concept of space.

From the writer's interview with the teacher, the child experienced obstacles in the concept of space, the child was always confused if she was given instruction by the teacher 
about the concept of space. Like at the time of the flag ceremony the teacher sent the child to one step forward then the child's actions just spin in place. Various attempts were made by the teacher so that children understand the concept of space as teachers always remind the child at rest that eating using the right hand. Based on the information, the authors madethe observations on the child, proved the child has obstacles in aspects of the concept of space such as the child always wear reverse shoes, and wearing a skirt upside down, the child is still confused about the concept of right-left, and front-back.

Seeing these problems then the authors did the basic skills assessment of children. First the authors first didthe assesment to the child motoric, on the balance aspect the child less able to stand by using one foot both the left foot and right foot. Next on the space concept aspect of nineteen of space given items, the child can only do as many as five items, and can not do fourteen items. From the results of the assessment that has been done, then the results obtained include the child unable to show the right eye, raised the right hand, raised the left foot, and showing the left ear.

The problems above need to be resolved, how can the child understand the concept of space with a fun learning, increase the motivation to learn, able to develop creativity, encourage imagination, strengthen memory, adapt to friends, do with joy, need to think learning that overcomes problems of daily life without deviating from the learning objectives.

Through fantasy gymnastics according to the story, the child can express himself as freely as possible with movements that are not as difficult as jumping right, leaping to the left, running forward, looking back. Fantasy gymnastics according to the story is very interesting to do because it contains elements imitate the movements or behavior of human beings, animals, and the movement of objects. This allows the child to rejoice through stories of movement, moving right to left, front behind. Fantasy gymnastics according to the story can be done indoors or outdoors, not using a special space, done with various forms of movement such as raising a right-left hand, jumping to the right and left. Through fantasy gymnastics according to the story is expected to be able to improve the ability of the introduction of the concept of space for children with mild mental retardation.

Based on the description and problems above, the authors are interested to examine the things related to fantasy gymnastics according to the story in improving the ability to recognize the concept of space in children with mild mental retardation. The author tries to do research with the title " Improving the Ability of Introduction to Space Concept Through Fantasy Gymnastics According to the Story for Childrenwith mildmental retardation $X$ Class III in SLB Muhammadiyah Pauh IX Padang ".

\section{RESEARCH METHOD}

This research is an experimental research in the form of Single Subject Research (SSR). Experimental research is an activity carried out experiments to see whether or not the effect of the intervention / treatment of behavioral changes in the target (target behavior). This research using ABA design, done with three stages in this research.

In the first stage is done by looking at the ability of children to recognize the beginning of the concept of space is also called the name of the target behavior in the initial conditions before being given intervention or baseline (A1), the second stage is given treatment or intervention (B) to give a fantasy gymnastics according to the story, and in the third stage is the condition of the child's ability after intervention is no longer granted, in the third stage of this notice is given the ability of children without treatment baseline (A2). Observers performed on a child's mild mental retardation.

Variable in this research there are two variables, that are independent variable and dependent variable. The dependent variable in this study is the ability to knowthe concept of space, for the independent variables are gymnastics fantasy according to the story.

Data recording was conducted by researchers using a test instrument spec-aspect in identifying the concept of space, the selected recording is a recording capabilities to knowthe concept of children space to the frequency. Data collection tools in this study using the format of data collection in the Baseline condition (A1), Intervention (B) and baseline (A2).

1. Analysis of data in condition

The analysis referred in this study is the graph data of each condition with the steps:

a. Determining the length of the condition

b. Determine the direction tendency estimation

c. Stability level

d. Determining the trend of data distance

e. Range

f. Determining the level of change

2. Analysis between conditions

Sunanto [1] says starting analyzing data changes between conditions, stable data must precede the conditions to be analyzed. Because if the data varies (unstable) it will be difficult to interpret the effect of the intervention on the dependent variable

The components in the analysis in the analysis between conditions are:

1. Determine the number of variables that change

2. Determine the changes in direction

3. Determine the changes in the trend of stability

4. Determine the level of change

5. Determining the percentage of over lap condition data $\mathrm{A}$ and $\mathrm{B}$ 


\section{RESEARCH RESULT}

\section{A. Data Description}

Research data Single Subject Research analyzed using visual analysis of the data graph (Visual Analysis of Grafic Data). Data obtained from observations on the condition A1 (Baselinebefore given intervention), condition B (Intervention), and on the condition A2 (Baseline after no longer given intervention).

In this study, researchers conducted a study as many as 19 meetings with the details of five meetings to the baseline condition $\mathrm{A} 1$, while the intervention condition (B) shall not exceed from nine meetings, then five meetings to the baseline condition A2. Each meeting condition is measured by calculating the frequency.

Data on these conditions obtained through observation of the baseline (A1) is $8,6,5,5,5$, on the intervention condition (B) Data obtained 10, 11, 17, 16, 16, 17, 17 17,17 and on the baselinecondition(A2) obtained the data $17,17,18,18,18$. This result shows the increasing frequency of the ability to recognize the concept of space in children after being given treatment or intervention through fantasy gymnastics according to the story in the previous conditions.

The data obtained from these three conditions can be illustrated in the following graph:

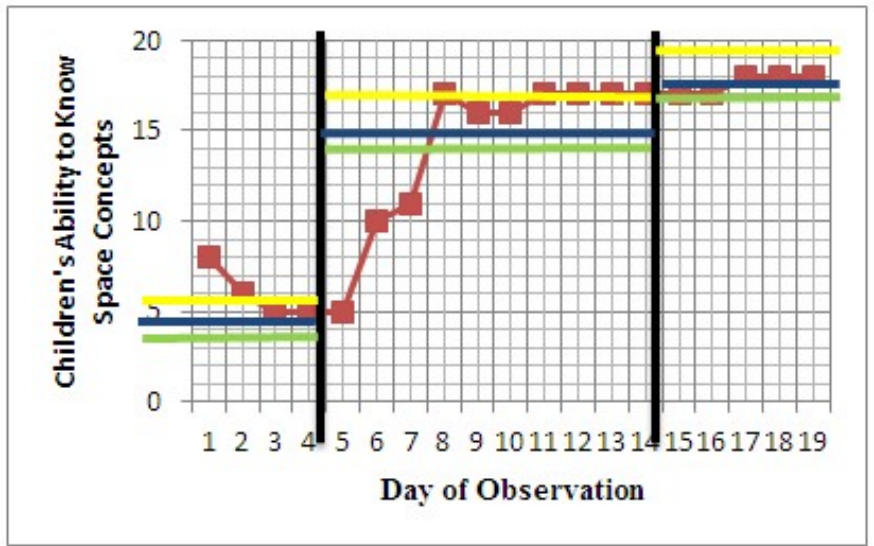

Graphic 1 Stabiliy of The Tendency of direction Increased the child'sAbility In Show, Mention, and Perform Space Concepts Information :

Mean Level

Upper limit

Lower limit

1. Analysis in Condition

Analysis under the conditions in this study is to analyze changes in existing data on the graph in each condition. The analysis component in this condition is shown in the table below:

Table 1 Analysis In Child suffered Lightweight mental retardation Condition IntroductionAbility of Space Concept (X)

\begin{tabular}{|c|c|c|c|c|}
\hline So & Conditions & $\mathbf{A}_{1}$ & B & $\mathbf{A}_{2}$ \\
\hline 1 & length conditions & 5 & 9 & 5 \\
\hline 2 & $\begin{array}{l}\text { Estimated tendency of } \\
\text { Directions }\end{array}$ & & & \\
\hline 3 & The tendency of Stability & $\begin{array}{l}20 \% \\
\text { (unstabl } \\
\text { e) }\end{array}$ & $\begin{array}{l}22,22 \% \\
\text { (unstab1 } \\
\text { e) }\end{array}$ & $\begin{array}{l}100 \% \\
\text { (stable) }\end{array}$ \\
\hline 4 & $\begin{array}{l}\text { The tendency of Footprint } \\
\text { Data }\end{array}$ & & & \\
\hline 5 & $\begin{array}{l}\text { Stability and Range } \\
\text { Levels }\end{array}$ & $\begin{array}{l}\text { Variable } \\
8-5\end{array}$ & $\begin{array}{c}\text { Variable } \\
10-17\end{array}$ & $\begin{array}{c}\text { Variable } \\
17-1 \mathrm{~s}\end{array}$ \\
\hline 6 & Level of Change & $\begin{array}{l}5-8 \\
(-)\end{array}$ & $\begin{array}{c}17-10 \\
(+)\end{array}$ & $\begin{array}{c}18-17 \\
(+)\end{array}$ \\
\hline
\end{tabular}

Summary of the results of visual analysis can be concluded that ability the introduction of the concept of space can be increasedthrough gymnastics fantasy according to the story.

\section{Analysis Between Condition}

Table 2 Results of Analysis SummaryInter Holding Error ConditionsTool Write

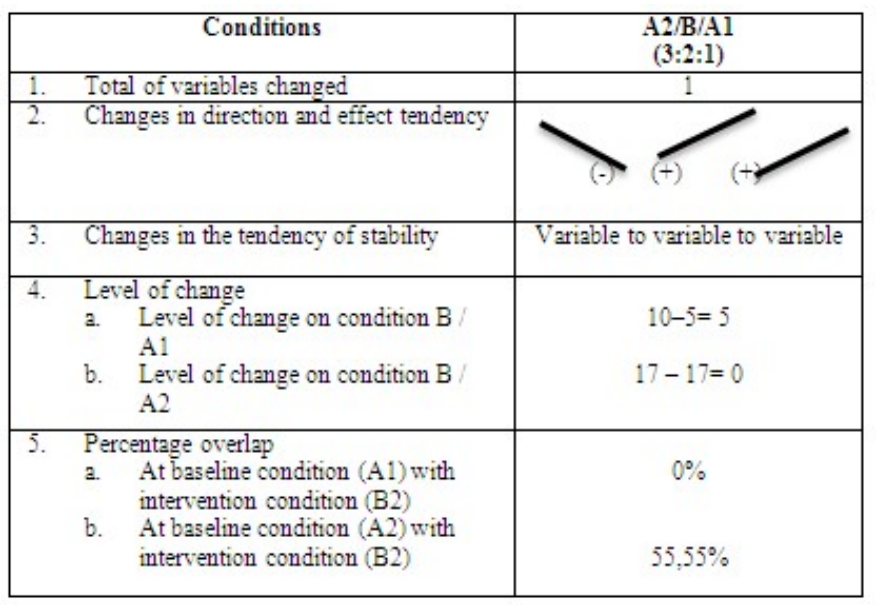

\section{DISCUSSION}

In this study, researchers increased the ability to know the concept of space through gymnastics fantasy story for children by children suffered mental retardation $X$. This research was conducted in three phases, namely the baseline phase (A1) before being given intervention, the intervention phase (B) that provide treatment, and the last phase of the baseline (A2) after being given treatment. The study was conducted for nineteen observations in three conditions, five times at the baseline condition before being given intervention (A1) and nine times under intervention condition (B) while at baseline condition, five observations after intervention no longer given .

At baseline condition (A1) shows the initial condition of the ability to show, state, and perform the concept of the descending space, which the child can not show, mention, and perform the concept of space which can be seen in graph 4.1 
from observations given for five days. Under conditions of intervention (B) after using fantasy gymnastics according to a story conducted during nine meetings, the results obtained tend to increase. It is seen in graph 4.2 that the observation day six the child has been able to answer ten questions correctly about the concept of space, at the seventh meeting the child able to answer eleven questions correctly about the concept of space, at the eighth meeting the child able to answer seventeen questions correctly about the concept of space, but at the ninth encounter the child's ability to answer questions decreases. The child was able to answer sixteen questions correctly, at the tenth meeting the children were able to answer sixteen questions correctly, while at the eleventh meeting up to the meeting of fourteen children were able to answer seventeen questions correctly.

In this baseline 2 (A2) condition, the researcher again observes the ability to show, mention, and perform the concept of space after the intervention was not given or stopped. Observations on these second baseline conditions were conducted over five days. The data obtained by the increase can be seen in graph 4.3 that at the observation of the day fifteenth and sixteenth, the child can answer seventeen questions correctly and then on the day seventeenth of observation until the observation of the nineteenth, the child can answer eighteen questions correctly about the concept of space.

The results obtained from the field in according with the theory of Elizabeth B. Hurlock [2] the concept of space is a person's ability to interpret an object in depth about the direction of right-left, front-back, top-down and is expected to be applied in daily life. So, in our daily lives we will never be separated from the concept of space as shorts, shoes, or put down an object. If one is not familiar with the concept of space then it will be difficult to socialize in everyday life. While the sense of fantasy gymnastics according to the story according to Samsudin, [3] Fantasy gymnastics according to the story of the child to do gestures as if a perpetrator in a story, or is experiencing an event. In this study a children suffered mental retardation perform gestures as if the main actors in a story. He expressed such movements as jumping to the right, leaping to the left, walking forward, looking back.

In a study of SSR in line with the opinions Sunanto [1] The frequency is the most simple and will not take much, that is by giving the sign (which provides a tally) on paper that has been provided any incident or behavior occurred up to the time period observations that have been determined.

Based on the results of research that has been done prove that the fantasy gymnastics according to the story can improve the ability of the introduction of the concept of space as a children suffered mental retardation class III in SLB Muhammadiyah Pauh IX Padang. This study is relevant to the study Rusjayanti [4] on " Improving the Ability to Know the Concept of Space Through Motion and Rhythmic Games In children with Class III Lightweight Tunagrahita in SDLB Tarantang Kabupaten Lima Puluh Kota ". Where the target behavior is the ability to recognize the concept of space and the independent variable is a motion and rhythm game with a child class II SDLB as the subject. The results of these observations seen an increased ability to recognize the concept of space.

Based on the above discussion, it can be concluded that the fantasy gymnastics according to the story can improve the ability of the introduction of the concept of space for children with mental retardation X in SLB Muhammadiyah Pauh IX Padang.

\section{References}

[1] Sunanto, Juang. 2005. Pengantar Penelitian dengan Subjek Tunggal. University Of Tsukuba, p.20, 117

[2] Hurlock, Elizabet B. 2000. Perkembangan Anak. Edisi Keenam., 41

[3] Samsudin. 2007. Pembelajaran Motorik di Taman Kanak-Kanak. Jakarta: Litera Prenada Media Group, 135.

[4] Rusjayanti. 2012. Meningkatkan Mengenal Konsep Arah Melalui Permainan Gerak Irama di SDLB Tarantang Kabupaten Limapuluhkota (thesis, no published). Padang: PLB FIP UNP. 